\title{
Pengaruh Insentif dan Pengembangan Karir terhadap Loyalitas Karyawan dengan Kepuasan Kerja sebagai Variabel Intervening pada CV. Mala Sari
}

Syati Manaharawan Siregar*

Fakultas Soshum dan Pendidikan Universitas Haji Sumatera Utara, Indonesia syatimanaharawan@gmail.com

\section{Nur Ainun}

Fakultas Soshum dan Pendidikan Universitas Haji Sumatera Utara, Indonesia nurainunnst65@gmail.com

\section{Surya Alamsyah Putra}

Prodi Manajemen, Sekolah Tinggi Ilmu Ekonomi Indonesia Medan, Indonesia suryaalamsyah85@gmail.com

This study aims to determine how much influence incentives and career
development and job satisfaction (intervening variables) have on loyalty in
CV. Malasari. This study uses a quantitative descriptive method with a
normative approach (legal research) to obtain secondary data and an
empirical approach (sociological juridical), to obtain primary data through
field research (field research). The results showed that the effect of
incentives, career development and job satisfaction on loyalty in CV.
Malasari, based on the indicators are as follows: First, the effect of incentives
on loyalty has a positive and significant effect which if it increases, loyalty
will also increase. Second, the influence of career development on loyalty
has a positive and significant effect where if career development increases,
loyalty will also increase. Third, the effect of job satisfaction on loyalty has
a positive and significant effect which means that job satisfaction increases,
loyalty will also increase. Fourth, the influence of career development on job
satisfaction has a positive effect, which means that if career development
increases, job satisfaction will also increase. Fifth, the effect of incentives on
job satisfaction has a positive effect, which means that if incentives increase,
job satisfaction will also increase. Sixth, the effect of career development on
loyalty that is intervened by job satisfaction is smaller than the direct effect
of career development on loyalty. Seventh, the effect of incentives on loyalty
that is intervened by job satisfaction is smaller than the direct effect of
incentives on loyalty. Which is better than the two variables, namely career
development and intensification not to be interfered with by job satisfaction.
For that, it is hoped that CV. Malasari in terms of improving loyalty so that
employees pay more attention to incentives, career development and job
satisfaction on CV. Malasari. In order to create good Loyalty in CV. Malasari
incentives, career development, job satisfaction, loyalty
Keyword




\section{PENDAHULUAN}

Dalam rangka meningkatkan kinerja, produktifitas dan laba (profit) serta mencegah terjadinya penyimpangan kesalahan prosedur, $\mathrm{Cv}$. malasari berupaya membuat dan selalu memperbaiki kinerja karyawannya dengan cara meningkatkan loyalitas sehingga diharapkan pendayagunaan atas kapasitas Sumber Daya Manusia di Cv. Malasari dapat ditingkatkan secara optimal. Dalam melaksanakan kegiatannya, perusahaan berusaha untuk mencapai tujuan yang telah ditetapkan. Satu hal yang penting yaitu bahwa keberhasilan berbagai aktivitas didalam perusahaan dalam mencapai tujuan bukan hanya bergantung pada keunggulan teknologi melainkan juga tergantung pada aspek Sumber Daya Manusia (SDM).

Sumber Daya Manusia (SDM) memegang peran penting dalam perkembangan perusahaan kedepannya. Berhasil atau tidaknya pencapaian tujuan perusahaan tersebut semua tergantung oleh kemampuan Sumber Daya Manusia (SDM) atau karyawan yang ada di perusahaan tersebut. Sumber daya manusia tersebut dituntut untuk terus dapat mengembangkan kemampuan secara proaktif di dalam perusahaan. Sumber daya manusia yang diperlukan perusahaan pada saat ini adalah sumber daya manusia yang mempunyai loyalitas kinerja yang tinggi pada perusahaan dan mampu membantu perusahaan dalam kondisi seperti apapun sehingga kepercayaan yang diberikan oleh perusahaan kepada karyawan tersebut akan terbalaskan dengan peningkatan loyalitas dari karyawan itu sendiri. Pentingnya loyalitas karyawan bagi perusahaan sangat berpengaruh agar dapat tercapainya apa yang diinginkan secara bersama.

Berbicara fenomena loyalitas yang ada di cv. Malasari adalah terjadinya ketimpangan tugas antara setiap karyawan hal ini menyebabkan lambannya dalam penyelesaian tugas karyawan di perusahaan tersebut, hal tersebut mungkin di sebabkan karena kurangnya insentif non material seperti uang atau jaminan sosial di perusahaan tersebut sehingga para karyawan bermalas malasan untuk bekerja karena tidak adanya kepastian dari perusahaan sehingga menurunnya loyalitas kerja karyawan. Menurut Jiwo Wungsu dan hartanto Broto Harsono (2003) "Insentif merupakan elemen atau balas jasa yang diberikan secara tidak tetap atau bersifat variabel tergantung pada kondisi pencapaian prestasi kerja karyawan”.

Dan Fenomena masalah lainnya adalah tentang pengembangan karir, pengembangan karir merupakan hal yang penting dalam mengembangkan dan memperhatikan sumber daya manusia. Pengembangan karir sangat mendukung efektivitas individu, kelompok dan organisasi dalam mencapai tujuan serta menciptakan loyalitas kerja. Karyawan di cv. Malasari akan merasa puas dalam bekerja apabila aspek-aspek pekerjaan dan dirinya mendukung. Persepsi setiap karyawan terhadap pengembangan karir bisa berbeda tergantung pada cara pandang karyawan terhadap faktor pengembangan karir. tidak adanya pelatihan khusus kepada karyawan dalam memposisikan jabatan tertentu sehingga pada saat sudah mendapat jabatan karyawan tersebut tidak memahami dengan fungsi, tugas dan pokoknya, fenomena yang sering terjadi juga kurang perhatiannya perusahaan kepada karyawan yang sudah lama untuk diberikan pelatiahan khusus agar dapat dipromosikan ke jabatan tertentu. Fenomena yang lain yang sering terjadi tidak adanya masa jabatan pada karyawan dalam menduduki suatu jabatan tertentu sehingga dapat menyebabkan praud di perusahaan tersebut. Gomes (2003) mengatakan: Pengembangan karir merupakan gabungan dari kebutuhan pelatihan di masa yang akan datang dan perencanaan sumber daya manusia (SDM). Dari sudut pandang pegawai atau karyawan, pengembangan karir memberikan gambaran mengenai jalur-jalur karir di masa yang akan datang di dalam organisasi dan menandakan kepentingan jangka panjang dari organisasi terhadap para karyawan atau pegawainya.

Dan Fenomena masalah lainnya adalah tentang Kepuasan kerja yang sering terjadi tidak 
sesuainya penerimaan insentif dan tidak adanya pengembangan karir membuat karyawan tidak mengoptimalkan kinerjanya sehingga loyalitas kinerja merekapun menurun hal ini dapat menjadi faktor pendukung dalam menurunnya loyalitas. Sopiah (2008) "Kepuasan kerja merupakan suatu tanggapan emosional seseorang terhadap situasi dan kondisi kerja". Sedangkan menurut Hasibuan (2009:202) "Kepuasan kerja adalah sikap emosional yang menyenangkan dan mencintai pekerjaan". Sikap ini dicerminkan oleh moral kerja, kedisiplinan dan prestasi kerja. Kepuasan kerja dinikmati dalam pekerjaan, luar pekerjaan dan kombinasi antar keduanya.

Karyawan akan mampu dan mau bekerja dengan baik bila memiliki kepuasan kerja apabila kebutuhannya sesuai dengan minat dan kemampuan serta dapat memenuhi berbagai kebutuhan dengan melakukan pekerjaan. Keadaan emosional sesorang yang bisa terlihat melalui tingkah laku dan sikap baik menyenangkan maupun tidak menyenangkan terhadap pekerjaan yang dilakukan para karyawan, yang pada dasarnya bersifat individual dan setiap individu memiliki tingkat kepuasan yang berbeda-beda sesuai dengan sistem nilai yang berlaku pada diri setiap karyawan

\section{METODE}

Metode penelitian merupakan cara yang digunakan oleh peneliti dalam mengumpulkan data penelitiannya, menurut Sugiyono (2012:2) Metode penelitian pada dasarnya merupakan cara ilmiah untukmendapatkan data dengan tujuan dan kegunaan tertentu.Pendekatan penelitian yang digunakan dalam penelitian ini adalah metode kuantitatif. Menurut Siregar (2015:125) menyatakan pendekatan kuantitatif adalah suatu proses dalam memperoleh data ringkasan dengan menggunakan cara - cara atau rumusan tertentu. Pada jenis riset ini biasanya dinyatakan kedalam angka dan numerik, yang dapat dibedakan menjadi data interval. Dimana data interval yaitu data yang diukur dengan jarak dua titik pada skala yang diketahui misalnya mengukur tingkat kepuasan dengan memilih angka 5,4,3,2,1 yang memiliki jarak yang sama.

\section{HASIL DAN PEMBAHASAN}

Variabel loyalitas

\begin{tabular}{|c|c|c|c|c|c|c|}
\hline \multirow{2}{*}{ No } & \multirow{2}{*}{ Pernyataan } & \multicolumn{5}{|c|}{ Persentase } \\
\hline & & SS & $\mathbf{S}$ & $\mathbf{N}$ & TS & STS \\
\hline 1 & Saya adalah karyawan yang taat pada peraturan. & 19.6 & 71.6 & 8.8 & & \\
\hline 2 & $\begin{array}{l}\text { Saya selalu mengikuti peraturan yang ada di } \\
\text { kantor. }\end{array}$ & 27.5 & 62.7 & 9.8 & & \\
\hline 3 & Saya selalu menjalankan peraturan yang ada & 17.6 & 67.5 & 14.7 & & \\
\hline 4 & Saya adalah karyawan yang bertanggung jawab. & 20.6 & 57.8 & 20.6 & 1.0 & \\
\hline 5 & Saya tidak pernah lari dari tanggung jawab saya & 12.7 & 63.7 & 22.5 & 1.0 & \\
\hline 6 & Saya tipekal pemegang teguh tanggung jawab & 18.6 & 58.8 & 22.5 & & \\
\hline 7 & Saya senang bekerja beramai ramai & 21.6 & 63.7 & 14.7 & & \\
\hline 8 & Saya adalah karyawan yang mudah bergaul. & 16.7 & 66.7 & 15.7 & 1.0 & \\
\hline 9 & Saya selalu di senangi oleh teman sekerja saya & 17.6 & 67.6 & 14.7 & & \\
\hline & Sampel & 102 & 102 & 102 & 102 & 102 \\
\hline
\end{tabular}

Dari tabel diatas terlihat bahwa nilai penjumlahan dari pernyataan sangat setuju (SS) sebesar 176, dan nilai pernyataan setuju (S) sebesar 592 dan nilai pernyataan netral (N) sebesar 147 dan nilai dari 
pernyataan tidak setuju (TS) sebesar 3. maka dengan demikian kebanyakan responden menjawab dengan pernyataan setuju.

\section{Variabel insentif}

\begin{tabular}{|c|c|c|c|c|c|c|}
\hline \multirow{2}{*}{ No } & \multirow{2}{*}{ Pernyataan } & \multicolumn{5}{|c|}{ Persentase } \\
\hline & & SS & $\mathbf{S}$ & $\mathbf{N}$ & TS & STS \\
\hline 1 & $\begin{array}{l}\text { Gaji yang telah diberikan oleh perusahaan kepada saya } \\
\text { sudah memenuhi kebutuhan minimal. }\end{array}$ & 19.6 & 69.6 & 10.8 & & \\
\hline 2 & $\begin{array}{l}\text { Pekerjaan saya yang berisiko tinggi tidak dipenuhi dengan } \\
\text { insentif langsung yang memadai. }\end{array}$ & 20.6 & 70.6 & 8.8 & & \\
\hline 3 & $\begin{array}{l}\text { Tunjangan hari raya yang diberikan oleh perusahaan } \\
\text { kepada saya setiap tahun sudah mencukupi kebutuhan saya }\end{array}$ & 26.5 & 67.6 & 5.9 & & \\
\hline 4 & $\begin{array}{l}\text { Selain gaji, insentif, dan tunjangan, saya juga memperoleh } \\
\text { bonus yang diberikan oleh perusahaan atas dedikasi dan } \\
\text { komitmen loyalitas saya. }\end{array}$ & 31.4 & 58.8 & 9.8 & & \\
\hline 5 & $\begin{array}{l}\text { Anda memperoleh asuransi kesehatan yang memadai untuk } \\
\text { menjamin kesehatan dan biaya pengobatan beserta } \\
\text { keluarga. }\end{array}$ & 17.6 & 71.6 & 10.8 & & \\
\hline 6 & $\begin{array}{l}\text { Anda menerima jaminan hari tua yang memadai untuk } \\
\text { menjamin kehidupan anda pada saat pensiun. }\end{array}$ & 20.6 & 69.6 & 9.8 & & \\
\hline 7 & $\begin{array}{l}\text { Insentif yang sedikit menyebabkan kinerja karyawan } \\
\text { menurun. }\end{array}$ & 23.5 & 69.6 & 6.9 & & \\
\hline 8 & $\begin{array}{l}\text { Kurang adanya tanggung jawab dalam bekerja sehingga } \\
\text { berpengaruh terhadap insentif yang diterimanya. }\end{array}$ & 18.6 & 70.6 & 10.8 & & \\
\hline 9 & $\begin{array}{l}\text { insentif yang besar menjadi pemicu semangat untuk } \\
\text { meningkat kinerja }\end{array}$ & 26.5 & 67.6 & 5.9 & & \\
\hline 10 & $\begin{array}{l}\text { Pencapaian kinerja yang maksiamal mendapatkan kualitas } \\
\text { yang tinggi. }\end{array}$ & 31.4 & 58.8 & 9.8 & & \\
\hline & Sampel & 102 & 102 & 102 & 102 & 102 \\
\hline
\end{tabular}

Dari tabel diatas terlihat bahwa nilai penjumlahan dari pernyataan sangat setuju (SS) sebesar 241, dan nilai pernyataan setuju (S) sebesar 688, dan nilai pernyataan netral (N) sebesar 91. maka dengan demikian kebanyakan responden menjawab dengan pernyataan setuju.

Variabel pengembangan karir

\begin{tabular}{clccccc}
\hline \multirow{2}{*}{ No } & \multicolumn{1}{c}{ Pernyataan } & \multicolumn{4}{c}{ Persentase } \\
\cline { 3 - 7 } & SS & S & N & TS & STS \\
\hline 1 & $\begin{array}{l}\text { Pimpinan memberikan kepercayaan pada bawahan untuk } \\
\text { dapat menyelesaikan pekerjaan }\end{array}$ & 26,5 & 66,7 & 6,9 & \\
\hline 2 & $\begin{array}{l}\text { Pimpinan memiliki kepercayaan tinggi terhadap } \\
\text { karyawannya }\end{array}$ & 25,5 & 73,5 & & & 1,0 \\
\hline 3 & Pimpinan selalu memperhatikan kondisi karyawannya & 21,6 & 73,5 & 2,9 & 2,0 & \\
\hline 4 & Pimpinan dapat memenuhi kebutuhan karyawanya & 11,8 & 64,7 & 11,8 & 10,8 & 1,0 \\
\hline 5 & Pimpinan dapat mengahargai pekerjaan karyawannya & 24,5 & 73,5 & 1,0 & 1.0 & \\
\hline 6 & $\begin{array}{l}\text { Pimpinan mendengarkan dan dapat menerima pendapat } \\
\text { karyawannya. }\end{array}$ & 32, & 61,8 & 2,9 & 2,9 & \\
\hline
\end{tabular}


Jurnal Ekonomi \& Ekonomi Syariah Vol 5 No 1, Januari 2022

E-ISSN : 2599-3410 | P-ISSN : 2614-3259

DOI : https://doi.org/10.36778/jesya.v5i1.605

\begin{tabular}{lllllllll}
\hline 7 & $\begin{array}{l}\text { Pimpinan dapat memotivasi karyawan untuk bekerja } \\
\text { maksimal. }\end{array}$ & 20.6 & 59.8 & 8.8 & 4.9 & 5.9 \\
\hline 8 & $\begin{array}{l}\text { Pimpinan dapat menginstruksikan pekerjaan } \\
\text { spesifik kepada karyawan. }\end{array}$ & secara & 28.4 & 61.8 & 1.0 & 6.9 & 2.0 \\
\hline 9 & $\begin{array}{l}\text { Pimpinan selalu memberikan ide-ide yang baik. } \\
10\end{array}$ & 18.6 & 58.8 & 22.5 & \\
\hline 11 & $\begin{array}{l}\text { Pemimpin memiliki inovasi yang tinggi dalam bekerja. } \\
\text { bekerja. }\end{array}$ & 21.6 & 63.7 & 14.7 & \\
\hline 12 & $\begin{array}{l}\text { Pimpinan dapat menjelaskan hal-hal penting dengan } \\
\text { sederhana dan mudah di mengerti. }\end{array}$ & 17.6 & 67.5 & 14.7 & & \\
\hline & & Sampel & 102 & 102 & 102 & 102 & 102 \\
\hline
\end{tabular}

Dari tabel diatas terlihat bahwa nilai penjumlahan dari pernyataan sangat setuju (SS) sebesar 271, dan nilai pernyataan setuju (S) sebesar 808, dan nilai pernyataan netral (N) sebesar 105, dan nilai dari pernyataan tidak setuju (TS) sebesar 30, dan nilai dari pernyataan sangat tidak setuju (STS) sebesar 10 . maka dengan demikian kebanyakan responden menjawab dengan pernyataan setuju.

Variabel kepuasan kerja

\begin{tabular}{|c|c|c|c|c|c|c|}
\hline \multirow{2}{*}{ No } & \multirow{2}{*}{ Pernyataan } & \multicolumn{5}{|c|}{ Persentase } \\
\hline & & SS & $\mathbf{S}$ & $\mathbf{N}$ & TS & STS \\
\hline 1 & $\begin{array}{l}\text { Gaji diberikan sesuai dengan jasa yang diberikan kepada } \\
\text { perusahaan. }\end{array}$ & 16.7 & 73.5 & 9.8 & & \\
\hline 2 & Pembagian insentif telah sesuai dengan prestasi kerja. & 19.6 & 70.6 & 9.8 & & \\
\hline 3 & $\begin{array}{l}\text { Semua karyawan diberikan peluang yang sama untuk } \\
\text { promosi. }\end{array}$ & 18.6 & 76.5 & 4.9 & & \\
\hline 4 & $\begin{array}{l}\text { Karyawan dengan prestasi baik memperoleh peluang untuk } \\
\text { di promosikan. }\end{array}$ & 25.5 & 55.9 & 10.8 & 7.8 & \\
\hline 5 & $\begin{array}{l}\text { Atasan memberikan masukan-masukan disaat karyawan } \\
\text { dalam kesusahan. }\end{array}$ & 13.7 & 76.5 & 8.8 & 1.0 & \\
\hline 6 & $\begin{array}{l}\text { Atasan selalu memberikan pengarahan kepada bawahan } \\
\text { disetiap pekerjaan. }\end{array}$ & 18.6 & 70.6 & 9.8 & 1.0 & \\
\hline 7. & $\begin{array}{l}\text { Suasana kekeluargaan dalam bekerja telah terjalin dengan } \\
\text { baik. }\end{array}$ & 21.6 & 64.7 & 9.8 & 1.0 & 2.9 \\
\hline 8. & $\begin{array}{l}\text { Rekan kerja selalu memberi nasehat dan saling membantu } \\
\text { dalam menyelesaikan pekerjan. }\end{array}$ & 24.5 & 61.8 & 9.8 & 2.9 & 1.0 \\
\hline 9 & $\begin{array}{l}\text { Pekerjaan yang diberikan didukung dengan fasilitas yang } \\
\text { memadai. }\end{array}$ & 19.6 & 70.6 & 9.8 & & \\
\hline 10 & $\begin{array}{l}\text { Pekerjaan yang diberikan sesuai dengan kemampuan } \\
\text { karyawan. }\end{array}$ & 18.6 & 76.5 & 4.9 & & \\
\hline 11 & $\begin{array}{l}\text { Suasana kekeluargaan dalam bekerja telah terjalin dengan } \\
\text { baik. }\end{array}$ & 16.7 & 73.5 & 9.8 & & \\
\hline 12 & $\begin{array}{l}\text { Rekan kerja selalu memberi nasehat dan saling membatu } \\
\text { dalam menyelesaikan pekerjanan. }\end{array}$ & 19.6 & 70.6 & 9.8 & & \\
\hline & Sampel & 102 & 102 & 102 & 102 & 102 \\
\hline
\end{tabular}


238, dan nilai pernyataan setuju (S) sebesar 858, dan nilai pernyataan netral (N) sebesar 110, dan nilai dari pernyataan tidak setuju (TS) sebesar 14, dan nilai pernyataan setuju tidak setuju (STS) sebesar 4. maka dengan demikian kebanyakan responden menjawab dengan pernyataan setuju.

Pengaruh insentif terhadap loyalitas, dari hasil penelitian bahwa H0 di tolak, yang artinya bahwa insentif berpengaruh positif terhadap loyalitas di CV. Malasari sebesar 16,9 \%. Dengan demikian apabila Insentif membaik maka loyalitas juga akan membaik di CV malasari. Pengaruh pengembangan karir terhadap loyalitas, dari hasil penelitian bahwa H0 di tolak, yang artinya bahwa variabel pengembangan karir berpengaruh positif terhadap loyalitas sebesar 50,9\%. Dengan demikian apabila pengembangan karir membaik di CV. Malasari maka Loyalitas juga akan membaik di CV. Malasari. Pengaruh kepuasan kerja terhadap loyalitas, dari hasil penelitian bahwa variabel kepuasan kerja berpengaruh positif terhadap loyalitas di CV. Malasari sebesar $20.6 \%$. Dengan demikian artinya semakin baik kepuasan kerja di CV. Malasari maka semakin baik juga loyalitas karyawan di CV. Malasari. Pengaruh pengembangan karir terhadap kepuasan kerja, dari hasil penelitian bahwa variabel pengembangan karir berpengaruh positif terhadap kepuasan kerja di CV. Malasari sebesar 38,6 \%. Dengan demikian artinya semakin baik pengembangan karir di CV. Malasari maka semakin baik juga kepuasan kerja di CV. Malasari. Pengaruh insentif terhadap kepuasan kerja, dari hasil penelitian bahwa variabel insentif berpengaruh positif terhadap kepuasan kerja di CV. Malasari sebesar $5.7 \%$. Dengan demikian artinya semakin baik Insentif di CV. Malasari maka semakin baik juga kepuasan kerja di CV. Malasari. Pengaruh pengembangan karir terhadap loyalitas yang di mediasi oleh kepuasan kerja,

Dari hasil penelitian ditunjukkan bahwa variabel pengembangan karir berpengaruh positif terhadap loyalitas dan pengembangan karir juga berpengaruh positif terhadap kepuasan kerja di CV. Malasari. Dengan demikian artinya semakin baik pengembangan karir di CV. Malasari maka semakin baik juga loyalitas dan kepuasan kerja di CV. Malasari. Adapun kepuasan kerja disini adalah bertindak sebagai variabel mediasi atau intervening. Dan hasil penelitian menunjukkan hasil perkalian antara (pengembangan karir $\mathrm{x}$ kepuasan kerja) lebih kecil dari pada hasil yang di tunjukkan oleh pengembangan karir terhadap loyalitas secara langsung. Maka dari itu untuk meningkatkan loyalitas sebaiknya pengembangan karir tidak di mediasi oleh kepuasan kerja , karena apabila pengembangan karir membaik maka secara otomatis kepuasan kerja juga akan membaik dan loyalitas juga akan meningkat di PT. CV. Malasari. Pengaruh insentif terhadap loyalitas yang di mediasi oleh kepuasan kerja, Dari hasil penelitian ditunjukkan bahwa variabel insentif berpengaruh positif terhadap loyalitas dan insentif juga berpengaruh positif terhadap kepuasan kerja di CV. Malasari. Dengan demikian artinya semakin baik Insentif di CV. Malasari maka semakin baik juga loyalitas dan kepuasan kerja di CV. Malasari. Adapun kepuasan kerja disini adalah bertindak sebagai variabel mediasi atau intervening. Dan hasil penelitian menunjukkan hasil perkalian antara (insentif $\mathrm{x}$ kepuasan kerja) lebih kecil dari pada hasil yang di tunjukkan oleh insentif terhadap loyalitas secara langsung. Maka dari itu untuk meningkatkan loyalitas sebaiknya insentif tidak di mediasi oleh kepuasan kerja , karena apabila insentif membaik maka secara otomatis kepuasan kerja juga akan membaik dan loyaliatas juga akan meningkat di CV. Malasari

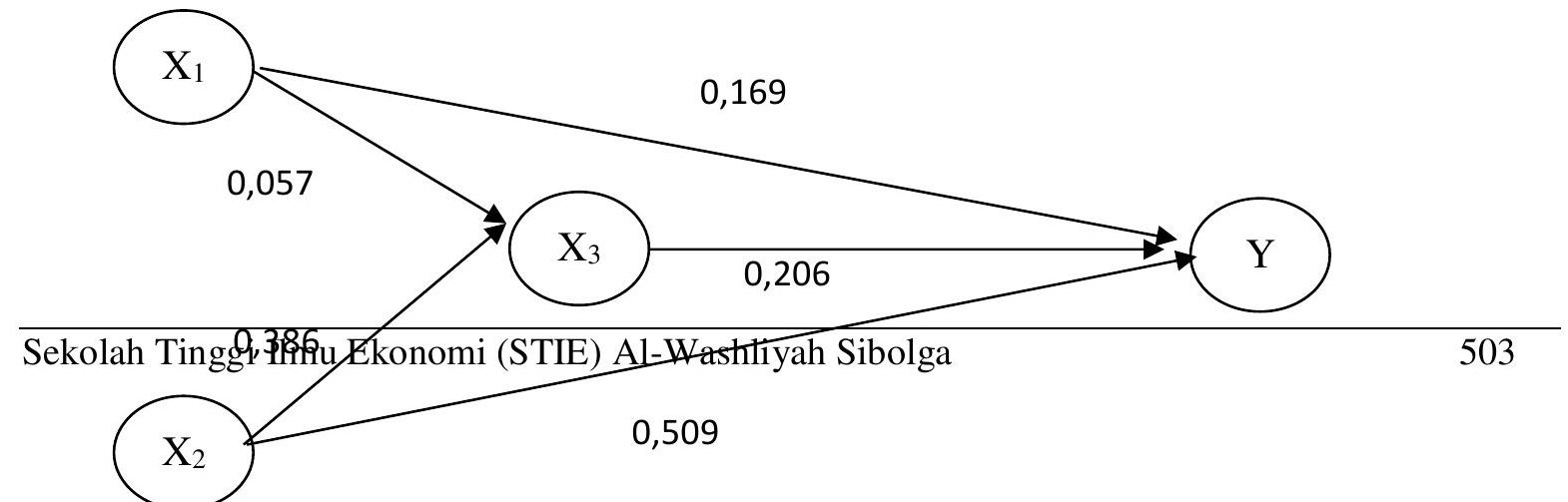




\section{KESIMPULAN}

Berdasarkan hasil analisis yang telah di bahas pada bab terdahulu, maka dapat diambil kesimpulan; hasil penelitian menunjukkan bahwa ada pengaruh positif dan signifikan antara variabel insentif dengan variabel loyalitas.H asil penelitian menunjukkan bahwa ada pengaruh positif dan signifikan antara variabel pengembangan karir dengan variabel loyalitas. Hasil penelitian menunjukkan bahwa ada pengaruh positif dan tidak signifikan antara variabel kepuasan kerja terhadap loyalitas. Hasil penelitian menunjukkan bahwa ada pengaruh positif antara variabel pengembangan karir terhadap kepuasan kerja. Hasil penelitian menunjukkan bahwa ada pengaruh positif antara variabel insentif terhadap kepuasan kerja. Hasil penelitian menunjukkan bahwa variabel pengembangan karir terhadap loyalitas sebaiknya tidak di mediasi oleh kepuasan kerja. Hasil penelitian menunjukkan bahwa insentif terhadap loyalitas sebaiknya tidak di mediasi oleh kepuasan kerja

\section{REFERENSI}

A. Sihotang. 2007. Manajemen Sumber Daya Manusia. Jakarta : Pradnya

AA. Anwar Prabu Mangkunegara, 2000. Manajemen Sumber Daya Manusia. Bumi Aksara.

Amsudin, Sadili. 2010. Manajemen Sumber Daya Manusia. Bandung : Pustaka Setia

Angga Rahyu Shaputra dan Susi Hendriani. 2015. Pengaruh Kompetensi, Komitmen Dan Pengembangan Karir Terhadap Kinerja Karyawan PT. Bank Rakyat Indonesia (Persero)

Kantor Wilayah Pekanbaru. Jurnal Tepak Manajemen Bisnis Vol VII No 1 Januari 2015

Bambang, Wahyudi, (2002). Manajemen Sumber Daya Manusia. Cetakan Ketiga. Bandung: PT. Remaja Rosdakarya

Bedjo Siswanto (2003). Manajemen Kerja Indonesia ( Pendidikan administrasi dan operatif) Jakarta: Bumi Aksara

Brotoharsojo, Hartanto \& Wungu, Jiwo, 2003, Tingkatkan Kinerja Perusahaan dengan Merit System, PT. Rajagrafindo Persada, Jakarta. Bumi Aksara, Jakarta.

Cook, J. D., dan T. D. Wall. (1980). New Work Attitute Measures of Trust, Organizations Commitment, and Personal Need Nonfullfillment. Journal of Accupational Psychology. pp. Denpasar: Astabrata Bali.

Dessler, Gary 2007. Manajemen Sumber Daya Manusia. Alih bahasa: Eli Tanya. Penyunting Bahasa: Budi Supriyanto. Jakarta:Indeks.

Gaouzali, Saydam. 2000. Manajemen Sumber Daya Manusia (Suatu Pendekatan

George, R, Terry, Leslie W. Rue. 2003. Dasar-Dasar Manejemen. Jakarta: PT. Bumi Aksara

Gomes, Faustino Cardoso. 2003. Manajemen Sumber Daya Manusia. Edisi II, Andi, Yogyakarta.

Gomes, Faustino Cardoso. 2003. Manajemen Sumber Daya Manusia. Edisi II, Andi, Yogyakarta.

Gorda, I Gusti Ngurah. 2006. Manajemen Sumber Daya Manusia, Edisi Revisi.

Handoko, T. Hani, 2001. Manjemen Personalia dan Sumber Daya Manusia. Yogyakarta. Bpfe

Hasibuan, Malayu S.P. 2005. Manajemen Sumber Daya Manusia, Edisi Revisi.

Heidjrachman et al. 2002. Manajemen Personalia. Edisi Empat. Yogyakarta. Bpfe

Henry Simamora. 2013. Paduan Perilaku Konsumen, Jakarta: Gramedia

Jakarta: Penerbit Gunung Agung. 


\section{JESYA}

JURNAL EKONOMI \& EKONOMI SYARIAH

Jurnal Ekonomi \& Ekonomi Syariah Vol 5 No 1, Januari 2022

E-ISSN : 2599-3410 | P-ISSN : 2614-3259

DOI : https://doi.org/10.36778/jesya.v5i1.605

Kuncoro, Mudrajad. 2002. Metode Kuantitatif. Teori dan Aplikasi untuk bisnis dan ekonomi,Unit Penerbit dan Percetakan YKPN. Yogyakarta.

Lambert, Eric dan Nancy Hogan. 2008. "The Importance of Job Satisfaction and Mikro. Jakarta: Djambatan.

Moeheriono. 2012. Pengukuran Kinerja Berbasis Kompetensi. Jakarta: Raja Grafindo Persada

Notoatmodjo, Soekidjo. (2009). Pengembangan Sumber Daya Manusia. Jakarta:

Notoatmodjo, Soekidjo. (2009). Pengembangan Sumber Daya Manusia. Jakarta:

P. Siagian, Sondang.2002. Kepemimpinan Organisasi \& Perilaku Administrasi,

Pandey, C. dan Khare R. 2012. "Impact of Job Satisfaction and Organizational Commitment on Employee Loyalty”. International Journal of Social Science \& Interdisciplinary Research. Vol.1.

Panggabean, S. Mutiara. 2004. Manajemen Sumber Daya Manusia. Bogor: Ghalia. Indonesia.Paramita. Penerbit Gunung Agung, Jakarta Perusahaan. Bandung : PT Remaja Rosdakarya.

Robbins, S. dan Judge, T. 2008. Perilaku Organisasi. Edisi 12. Diterjemahkan

Robbins, Stephen P And Judge, Timotty A. 2009. Prilaku Organisasi-2. Salemba Empat, Jakarta.

Sarwoto (2000), dasar dasar organisasi dan manajemen, jakarta : ghalia indonesia

Siagian, Sondang P, 2006, Organisasi Kepemimpinan Dan Prilaku Administrasi,

Siswanto. 2012. Pengantar Manajemen: PT.Bumi Aksara, Jakarta

Sondang P. Siagian. 2011. Manajemen Sumber Daya Manusia, Jakarta: PT. Bumi

Sopiah. 2008, Steven L. McShane dan Mary Ann Von Glinow. 2000, Humen Resource and Personnel Perilaku Organisasional. Penerbit Andi, Yogyakarta.

Steers, Sakina. 2009, Efektivitas Kepemimpinan. Penerbit Deepublish, Yogyakarta. Management. Tata McGraw-Hill. New Delhi Sulita : Bandung

Sutrisno, Edi. 2009. Manajemen Sumber Daya Manusia Edisi pertama. Jakarta: Kencana Prenada Media Group

Van, Dyne, L, graham J.W. 2005. Organizational Citizenship Behavior, Construct

Veithzal Rivai, 2004, Manajemen Sumber Daya Manusia Untuk Perusahaan, Cetakan Pertama, Jakarta, PT. Raja Grafindo Persada. 